\title{
Financial comparative study between post-tensioned and reinforced concrete flat slab
}

\author{
Omar Ahmad
}

Civil Engineering Department, Near East University, Nicosia, Via Mersin 10, Turkey

\section{A RTICLE INFO}

\section{ARTICLE HISTORY:}

Received: 18 February 2021

Revised: 17 April 2021

Accepted: 05 May 2021

Published: 25 May 2021

\section{KEYWORDS:}

post-tensioned slab, flat slab, cost, concrete, steel bars, tendons

\section{A B S T R A C T}

\begin{abstract}
As for today, post-tensioned slabs gained much popularity and started to be widely used among construction companies all around the world. As we refer to the structural members, we acknowledge that the price of the slab is much higher in comparison to the other structural members like columns, beams, or foundation in accordance to the amount of steel and concrete in it. A comparative study has been done between post-tensioned, and reinforced concrete flat slab to compare how much each slab cost. It describes that since the post-tension slabs are thinner and it provides fewer columns, so the amount of concrete required is less than the required amount in a flat slab. Special steel tendons that are used in post-tensioned slabs will be stretched by a hydraulic jack after the casting of concrete, and these tendons have an effect in reducing the reinforcement steel bars. Although tendons are used only in post-tension slabs, the amount of steel used in it is less compared to flat slabs. Furthermore, the contractor work cost differs from doing the post-tensioned slab and flat slab. The study had been done by comparing the amount of concrete, steel and contractor work cost. The results obtained from the comparative study between post-tension slabs and reinforcement concrete flat slabs indicate that post-tensioned slabs are cheaper.
\end{abstract}

\section{INTRODUCTION}

There are many different types of slabs that used in structural buildings, for example, flat slab, hollow block slab, solid slabs, bubble deck slab, composite slabs, waffle slabs, dome slab, precast slabs and post-tensioned slabs. Each type of slab has advantages and disadvantages and each type has a case to be used according to the needs of a project. In certain structures such as cinemas, schools, university halls, parking places, airports, shopping malls or bridges, it is not preferable to place a column in the middle of these structures and at least there should be a long distance between the columns. Hence, during the construction of these structures, long spans are required. As we refer to the structural members, we know that the price of the slab is much higher in comparison to the other structural members like columns, beams, or foundation due to the amount of steel and concrete in it. The cost should be taken into consideration while choosing the type of slab. (Park \& Gamble, 1999).

In most countries, the most commonly used slabs are hollow block and reinforced concrete flat slabs. But recently post-tensioned slabs started to be widely used by many construction companies all around the world. Before pouring the concrete in post-tensioned slabs a high tensile steel tendons/cables are placed in the slab with the reinforcing steel bars. Before the loads are applied these high tensile tendons are pulled by hydraulic jacks and held in tension using specially designed anchorages fixed at each end of the tendon after pouring the concrete and achieving the desired strength that is around 20-23 days. This type of slab allows the concrete to overcome its weakness in tension and to make better use of its strength in compression. (Kakadiya et al., 2016).

\section{SCOPE OF STUDY}

In the designing process, the priority for the economy is selecting the structural system that offers the lowest overall cost while meeting load and code requirements. The aim of the study is to show the post-tensioned is more economical than the reinforced concrete flat slabs according to the amount of steel, concrete, tendons and the contractor cost. This study is so important because the role of civil engineer 
in the managing field is to save time, effort and money, and all owners looking for less cost for their projects.

\section{SLABS OVERVIEW}

\subsection{Reinforced concrete flat slabs}

Reinforced concrete flat slabs or beamless slab are widely all over the world, they are reinforced in two or more directions and it is supported by columns without intermediate beams in which the loads are directly transferred to the columns (Sahab et al., 2005). They are subjected to both vertical and lateral loads. Lateral loads are occurring because the wind and earthquake govern the design rather than the vertical loads. The design and analysis of it are complicated and take a long time. There are four types of reinforced concrete flat slabs which are with drop panel, with column head, with drop panel and column head or without drop panel and without column head. In 1906 the flat slabs had been constructed by turner, mainly using intuitive and conceptual ideas in the United States of America, which was the start of this type of construction. In 1914 Nicholas proposed a method of analysis of flat slabs based on simple statics (Patil \& Sigi, 2014). Flat slabs are mostly used in residential buildings, offices, hotels, schools and hospitals. Reinforced concrete structures with flat slab provide over conventional momentresisting frames. (Erberik \& Elnashai, 2004).

\subsubsection{Advantages of flat slab}

Advantages of flat slab are as follows:

- Easy placing of the steel reinforcement bars,

- Simplified formworks,

- Reduces the overall building height,

- Enables additional floor to the building,

- Compared to other types of slabs less weight of slab which leads to less dead load upon designing,

- Less time needed in the construction.

\subsubsection{Disadvantages of flat slab}

Disadvantages of flat slab are as follows:

- Due to the less depth, deflections tend to be large,

- Does not provide long spans,

- The Slab column connection does not have the rigidity of the beam-column joint,

- Deflection in the middle strip may be critical,

- Using of drop panels may interfere with mechanical ducting (Anjaneyulu \& Prakash, 2016; Tin, 2019).

\subsection{Post-tensioned slabs}

As for today, post-tensioned slabs gained much popularity and started to be widely used among construction companies all around the world especially in storage tanks and bridges (Moldovan \& Mathe, 2016). In India, the posttensioned slabs are not used in residential buildings or in another word it is not used in small span structures (Sahu et al., 2014). In Romania, the use of post-tensioned slab is avoided due to reduced knowledge in design (Török et al., 2019). In the post-tension slab, the reinforcement is replaced with cables/ steel tendons. There are two types of tendons in post-tensioned slabs: bounded and unbounded (Gupta et al., 2018). In a post-tensioned slab, the reinforcements are placed in the slab with other steel cables called tendons. These steel tendons have an ultimate tensile strength of 1860 Newton per square millimeters (MPa). These tendons are placed in the slab in a waved way in which they are concaved up at the negative moments and concaved down at the positive moments. (Thayapraba, 2014). The post-tensioned slabs with unbounded tendons allow the design of modern architectural building structure (Szydłowski \& Łabuzek, 2017).

Because of the high negative moment at the columns, these tendons are always concaved up at the columns. The placing of tendons is so easy and it is done by the posttensioned company according to the design. Since there are fewer reinforcing bars this helps in quicker installation and easier coordination between plumbing and electrical utilities. Tendons are installed with a dead-end that remains embedded in the concrete slab in the form of an onion and a live end that projects through the form. After casting of concrete on slab tendons are stressed by certified posttension tendons installers, verified with elongation measurements, and reviewed by the engineer of record of the slab by using a hydraulic jack. Once the tendons have been stressed and verified, anchors will be placed at the live ends, then the tendons will be trimmed and the live ends will be sealed with grout. (Rogers, 2008).

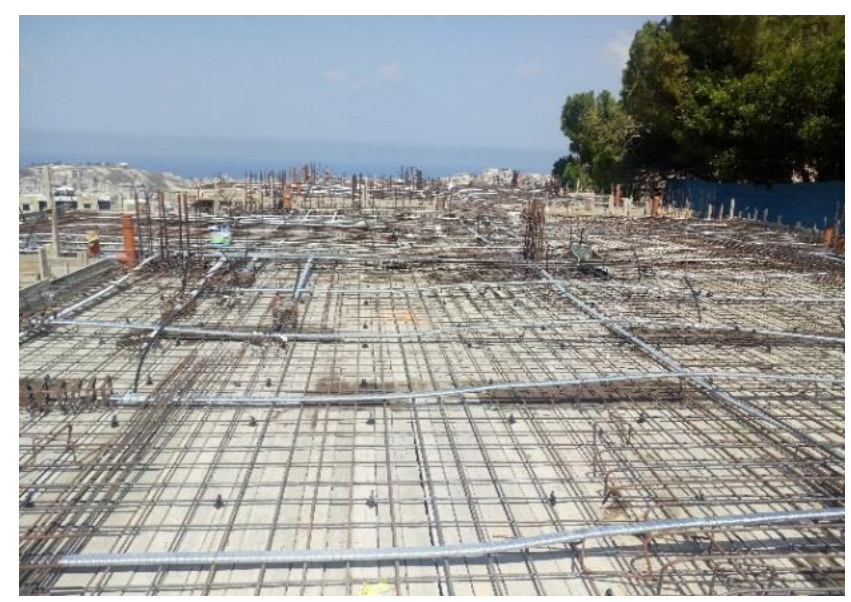

Fig. 1. post-tensioned slab 


\subsubsection{Advantages of post-tensioned slabs}

- Fewer materials used in construction,

- It reduces or eliminates shrinkage cracking,

- It provides long spans between the columns,

- It provides higher ultimate strength due to the bond between the strand and concrete,

- It allows the thinner thickness of slab and less dead load due to the own weight,

- It reduces the building height,

- It allows the architect to be free in designing due to column layout.

\subsubsection{Disadvantages of post-tensioned slab}

- It requires skilled labourers during the construction process,

- The placing of tendons must be accurate,

- It requires perfect supervision at all stages of construction (Al Rawi, 2020).

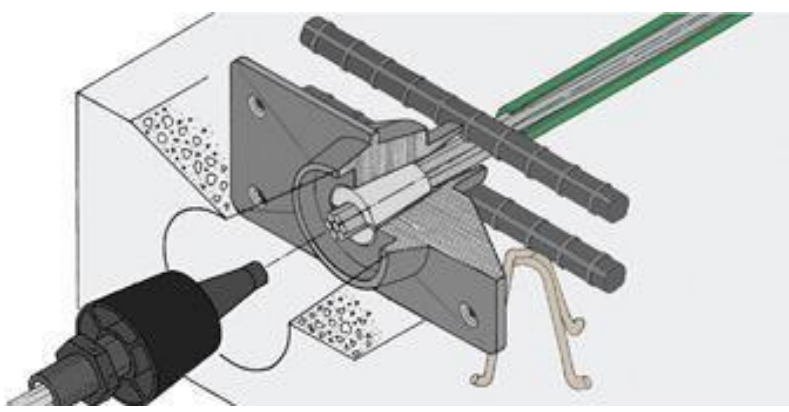

Fig. 2. stretching the tendons by hydraulic jack (Jim Rogers, 2008)

\section{METHODOLOGY}

The study had been done on a slab with the columns. The aim of making the study on slab with columns is because that they are not the same in the different types of slabs. Fig. 4 shows the location of columns, the dimensions and the distances between the columns. The quantity and cost of steel and concrete will be calculated and the contractor work cost.

Upon designing the slab, the strength of concrete in the post-tensioned slab should be $30 \mathrm{MPa}$ while it should be 25 $\mathrm{MPa}$ in a reinforced concrete flat slab. This difference in cost of the strength of concrete differs also in the cost of it in which the $30 \mathrm{MPa}$ concrete strength is more expensive by approximately 5 dollars compared to the $25 \mathrm{MPa}$. The yield strength of the steel bars the same in both types of slabs which is $400 \mathrm{MPa}$.

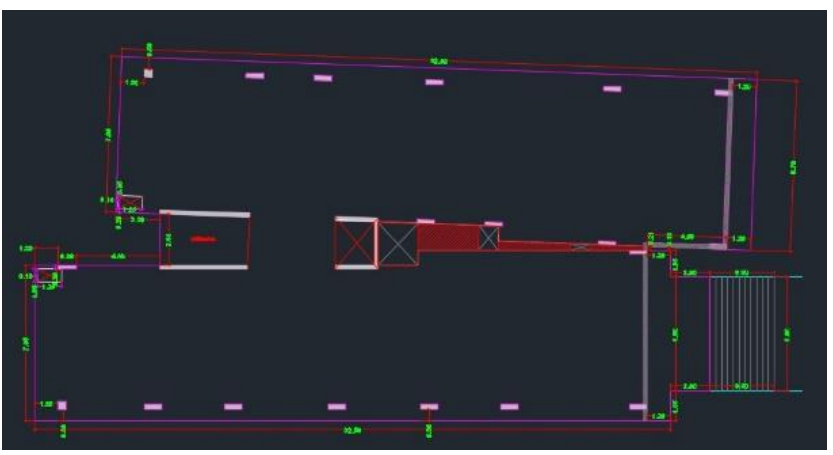

Fig. 3. The slab of study

Table 1. Material properties in both slabs

\begin{tabular}{|l|c|c|}
\hline & Post-tensioned slab & Flat slab \\
\hline Concrete strength (MPa) & 30 & 25 \\
\hline Steel strength (MPa) & 400 & 400 \\
\hline
\end{tabular}

If the slab would be flat slab the thickness should be 32 $\mathrm{cm}$ while if the slab would be a post-tensioned slab the thickness should be $26 \mathrm{~cm}$. The area of the slab had been calculated and it is $540 \mathrm{~m}^{2}$. By multiplying the area with the thickness of the slab, it will give the total volume of the slab.

Table 2. The volume of the flat and post-tensioned slabs

\begin{tabular}{|c|c|c|}
\hline & Post-tensioned slab & Flat slab \\
\hline Thickness (cm) & 26 & 32 \\
\hline Area $\mathbf{( m}^{\mathbf{2}}$ ) & 540 & 540 \\
\hline Volume $\left.\mathbf{( m}^{\mathbf{3}}\right)$ & 140.4 & 172.8 \\
\hline
\end{tabular}

The study had been done by calculating the quantities of concrete, steel bars, and tendons in both slabs and then estimating their cost with an estimation of contractor work cost to know how much each slab cost and according to the cost the more economical slab will be used.

First, the quantity of concrete had been compared in both slabs. According to the design, the post-tensioned slab provides longer spans so the number of columns in a posttensioned slab is 18 while it is 20 in a reinforced concrete slab. So, the amount of concrete poured in the column is by multiplying the dimensions of the column which are $90 \times 25$ $\mathrm{cm}$ by the height which is $3 \mathrm{~m}$ by the number of columns.

Table 3. Quantitates and cost of concrete

\begin{tabular}{|l|c|c|c|}
\hline \multicolumn{2}{|c|}{ Concrete } & Flat slab & $\begin{array}{c}\text { Post-tensioned } \\
\text { slab }\end{array}$ \\
\hline \multirow{2}{*}{ Columns } & Number & 20 & 18 \\
\cline { 2 - 4 } & Concrete $\left(\mathrm{m}^{3}\right)$ & 13.5 & 12.15 \\
\hline Slab & Concrete $\left(\mathrm{m}^{3}\right)$ & 172.8 & 140.4 \\
\hline Total $\left(\mathbf{m}^{\mathbf{3}}\right)$ & 186.3 & 152.55 \\
\hline Rate $\mathbf{\$})$ & 76 & 81 \\
\hline \multicolumn{2}{|l|}{ Total $\mathbf{( \$ )}$} & 14158.8 & 12356.55 \\
\hline
\end{tabular}




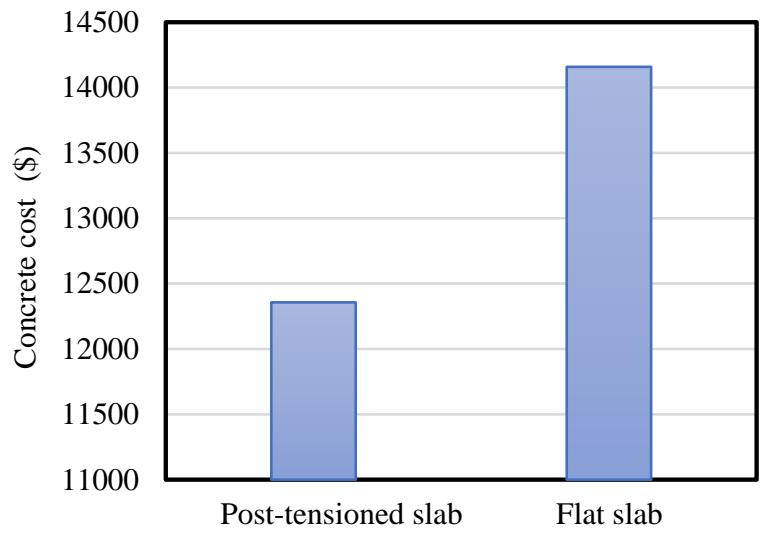

Fig. 4. Concrete cost comparison

Then the quantities of steel bars in both slabs had been calculated. The quantity of steel is multiplying the quantity of steel in each $\mathrm{m}^{3}$ by the volume.

Table 4. Quantities and cost of steel

\begin{tabular}{|l|c|c|}
\hline Steel & Flat slab & Post-tensioned slab \\
\hline Unit (kg) & 100 & 60 \\
\hline Total in slab (ton) & 17.28 & 8.424 \\
\hline Unit(kg) & 280 & 280 \\
\hline Total in columns (ton) & 3.78 & 3.402 \\
\hline Price rate (\$) & 700 & 700 \\
\hline Total price (\$) & 14742 & 8278.2 \\
\hline
\end{tabular}

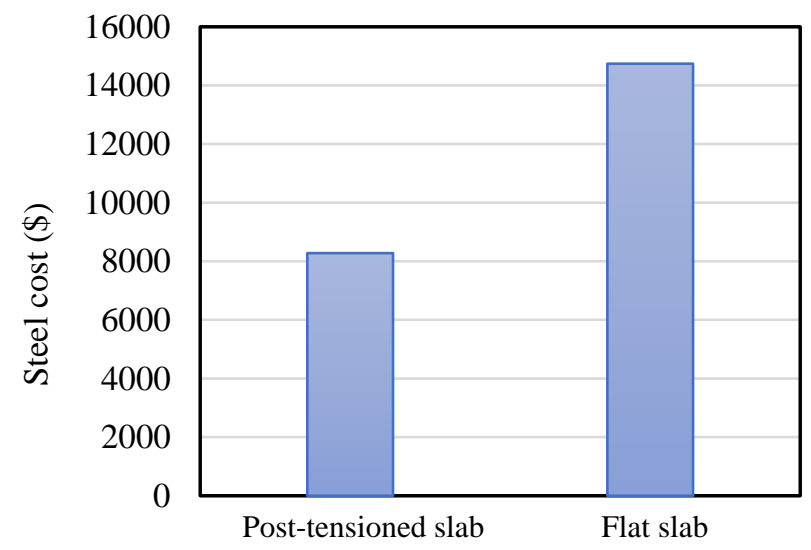

Fig. 5. Steel cost comparison

In a post-tensioned slab, there is additional steel (tendons) are used these tendons. The post-tension company takes 12.5 dollars for every $\mathrm{m}^{2}$.

Table 5. Cost of tendons

\begin{tabular}{|l|c|c|}
\hline Tendons & Flat slabs & Post-tensioned slabs \\
\hline Price rate (\$) & - & 12.5 \\
\hline Total price (\$) & - & 6750 \\
\hline
\end{tabular}

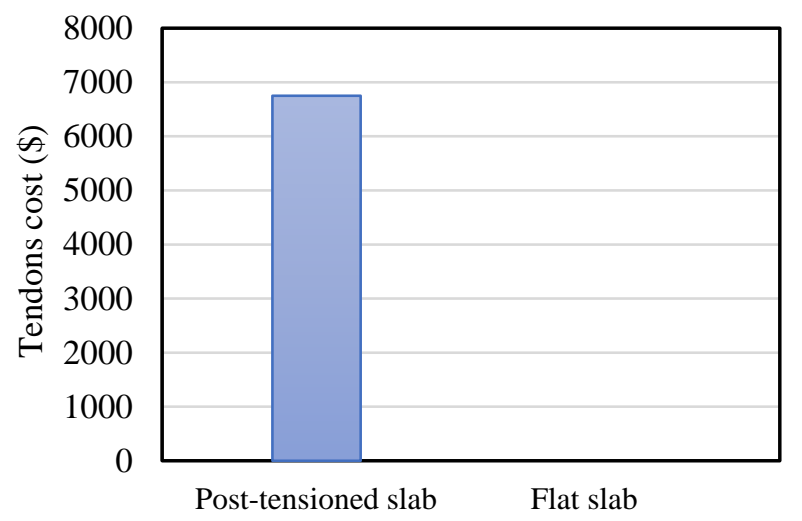

Fig. 6. Cost of tendons

The contractor work cost also affects the total cost of the slab because in the post-tension slab fewer columns used so the contractor cost will be less.

In the column, the contractor takes each column as $1 \mathrm{~m}^{3}$. Since in flat slab, there are 20 columns and in the posttensioned slab, there are 18 columns so the total work done by the contractor in both slabs is 20 and $18 \mathrm{~m}^{3}$ respectively. Also, the contractor takes for the slab as its volume which is $172.8 \mathrm{~m}^{3}$ for the flat slab and $140.4 \mathrm{~m}^{3}$ for the posttensioned slab.

Table 6. Cost of contractor work

\begin{tabular}{|l|c|c|}
\hline Contractor & Flat slab & Post-tensioned slab \\
\hline Columns $\left(\mathbf{m}^{\mathbf{3}}\right)$ & 20 & 18 \\
\hline Slab $\left(\mathbf{m}^{\mathbf{3}}\right)$ & 172.8 & 140.4 \\
\hline Total $\left(\mathbf{m}^{\mathbf{3}}\right)$ & 192.8 & 158.4 \\
\hline Price rate $\mathbf{( \$ )}$ & 30 & 30 \\
\hline Total price $\mathbf{( \$ )}$ & 5784 & 4752 \\
\hline
\end{tabular}

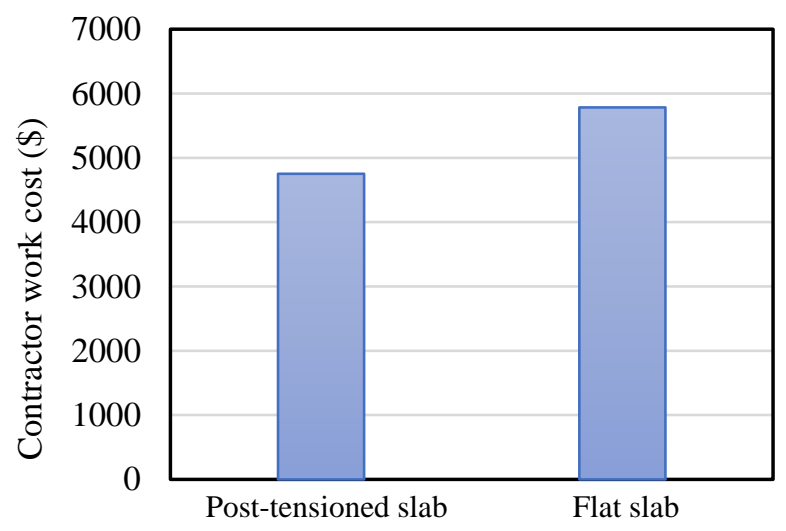

Fig. 7. Cost of contractor work 
Table 7. Total cost in both slabs

\begin{tabular}{|l|c|c|}
\hline Cost & Flat slab & $\begin{array}{c}\text { Post-tensioned } \\
\text { slab }\end{array}$ \\
\hline Concrete \$ & 14158.8 & 12356.55 \\
\hline Steel \$ & 14742 & 8278.2 \\
\hline Tendons \$ & - & 6750 \\
\hline Contractor \$ & 5784 & 4752 \\
\hline Total \$ & 34684.8 & 32136.75 \\
\hline
\end{tabular}

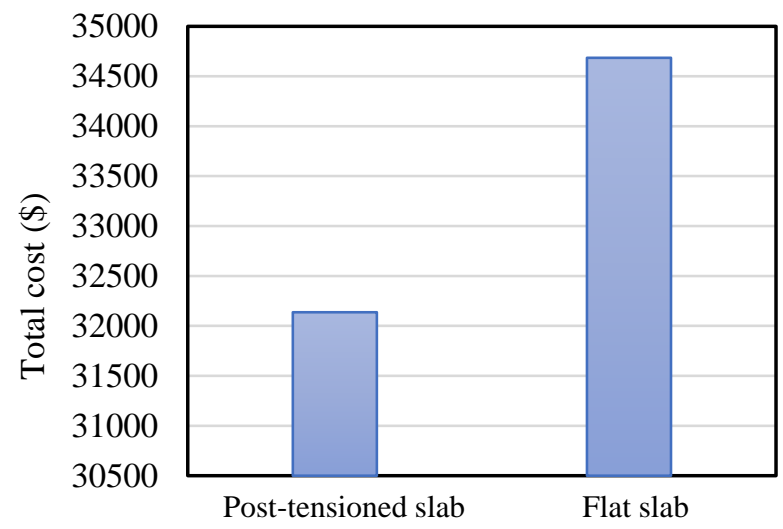

Fig. 8. The total cost of both slabs

\section{RESULTS AND DISCUSSION}

In table 3 the quantity of concrete in the columns and slab of flat slab $186.3 \mathrm{~m}^{3}$ which is more than in the posttensioned slab which is $152.55 \mathrm{~m}^{3}$ and although that the cost of concrete in post-tensioned is more expensive than in flat slab, after multiplying the total volume by the cost of concrete it showed that the post-tensioned slab is more economical than the flat slab.

In Table 4 the quantity of steel in the column and slab of the flat slab is 21.06 ton which is more than in the posttensioned slab which is 11.826 ton. Multiplying the total quantity of steel by the cost of it showed that the posttensioned slab is more economical.

In Table 5 there is an additional cost only on the posttensioned slab because there are no tendons in flat slabs.

In Table 6 the total work done by the contractor in flat slabs is much higher than in the post-tensioned slab which shows more contactor work cost in flat slabs than in posttensioned slab.

Table 7 shows that the total cost of constructing the flat slab is higher than the post-tensioned slab.

\section{CONCLUSION}

The comparative study of the reinforced concrete flat slab and post-tensioned slab structure is presented. The parameters considered in this research are the quantity and cost of concrete, steel and tendons and the contractor work cost. Thus, based on the analysis and after comparing the total cost it can be stated that the post-tensioned slab is more economical than the flat slab in which the owner can save money on each floor if the owner decided to use a posttensioned slab in the project.

\section{CONFLICT OF INTEREST STATEMENT}

The author(s) declare that there is no conflict of interest

\section{REFERENCES}

[1] Adan, S. M., Luft, R., \& Naguib, W. I. (2010). Deflection considerations in two-way reinforced concrete slab design. In Structures Congress 2010, San Francisco, 1991-2002.

[2] Al Rawi, Y., Temsah, Y., Baalbaki, O., Jahami, A., \& Darwiche, M. (2020). Experimental investigation on the effect of impact loading on behavior of posttensioned concrete slabs. Journal of Building Engineering, 31, 101207. https://doi.org/10.1016/j.jobe.2020.101207

[3] Anjaneyulu, B, Prakash, K. J. (2016). Analysis and design of flat slab by using Etabs software. International Journal of Science Engineering and Advance Technology, 4(2), 105-112.

[4] Erberik, M. A., \& Elnashai, A. S. (2004). Fragility analysis of flat-slab structures. Engineering Structures, 26(7), 937-948.

https://doi.org/10.1016/j.engstruct.2004.02.012

[5] Gupta, V., Sahu, R., \& Singh, P. (2018). Comparative analysis of conventional slab, flat slab and post tensioning slab. International Journal for Scientific Research \& Development, 6(3), 79-81.

[6] Kakadiya, M. G., Dhamaliya, H. K., \& Gadhiya, J. (2016). A research on comparison of RCC and post tensioned flat slab with or without drop using software. International Journal of Scientific Research in Science, Engineering and Technology, 2(2), 1132-1136.

[7] Moldovan, I., \& Mathe, A. (2016). A study on a twoway post-tensioned concrete waffle slab. Procedia Technology, 22, 227-234.

[8] Park, R., \& Gamble, W. L. (1999). Reinforced concrete slabs ( $2^{\text {nd }}$ ed.). John Wiley \& Sons, 1-9.

[9] Patil, S. S., \& Sigi, R. A. (2014). flat slab construction in India. International Journal of Engineering and Innovative Technology, 3(10), 138-141.

[10] Rogers, j. (2008). Post-tensioned slabs combining the advantages of prestressed and cast-in-place concrete. concrete construction. https://concreteconstruction.net/ 
[11] Sahab, M. G., Ashour, A. F., \& Toropov, V. V. (2005). Cost optimisation of reinforced concrete flat slab buildings. Engineering Structures, 27(3), 313-322. https://doi.org/10.1016/j.engstruct.2004.10.002

[12] Sahu, A., Rai, A., \& Bajpai, Y. K. (2014). Cost comparison between rcc \& post-tensioned prestressed beams spanning $26 \mathrm{~m}$. International Journal of Computational Engineering Research, 4(6), 11-14, 2250-3005.

[13] Szydlowski, R., \& Labuzek, B. (2017). Post-Tensioned Concrete Long-Span Slabs in Projects of Modern Building Construction. IOP Conference Series: Materials Science and Engineering, 245, 022065. https://doi.org/ 10.1088/1757-899x/245/2/022065

[14] Tin, N. (2019). comparative study of quantity and cost on post tensioned slab and reinforced concrete slab in structures. International Journal of Computer Science Trends and Technology, 7(5), 42-46.

[15] Thayapraba, M. (2014). Cost effectiveness of posttensioned and reinforced concrete flat slab systems. International Journal of Innovative Technology and Exploring Engineering, 3(2), 2278-3075.

[16] Török, I., Puskás, A., \& Virág, J. (2019). Posttensioned flat slabs with unbonded tendons for public buildings. Procedia Manufacturing, 32, 102-109. 